\title{
Analisis Dampak Pembelajaran Daring Bagi Pelajar Dalam Membentuk Keaktifan Belajar
}

\author{
Zikry Septoyadi*, Vita Lastriana Candrawati, Muhammad Mahyadien \\ Universitas Islam Indonesia, Yogyakarta, Indonesia \\ *20913050@students.uii.ac.id
}

\begin{abstract}
This research was motivated by the application of online learning during the pandemic causing the impact of its application in increasing student learning activity. Because in this era, learning to reduce the spread of the corona virus is done online or online. Online learning carried out at home is the responsibility of parents in supervising their children. The purpose of this study is to determine the impact on children in increasing student learning activeness in the application of online learning as well as to know the impact that occurs on parents of students whose children participate in online learning programs. This study uses a qualitative descriptive approach, in which the author is the main instrument for obtaining more detailed data. The object of this research is the community in Padukuhan Mlangi Sawahan. The technique of determining the informants in this study used purposive sampling. Data collection techniques in this study were observation, interviews, and documentation. Then the data that has been collected is analyzed using data reduction, data presentation, and conclusions. The results of this study were the implementation of online learning at Padukuhan Mlangi Sawahan, the students' learning activeness did not increase, students did not like learning that was done online. This made students become inactive, students depended a lot on their parents, students preferred direct learning in class. make this online learning students become bored. Then the impact on parents and children is that students have limited thinking space, making students unable to exchange opinions with other students and not being able to ask directly with the teacher, making students too dependent on their parents every time there is a task and making parents disturbed, parents have to add costs to buy an internet package so that children can follow the learning that is currently being applied, online learning for children and parents who are not familiar with the use of technology creates confusion with its use.
\end{abstract}

Keywords: impact; online learning; learning activeness

\begin{abstract}
ABSTRAK
Penelitian ini dilatar belakangi oleh penerapan pembelajaran daring di masa pandemi menimbulkan dampak dari penerapannya dalam meningkatkan keaktifan belajar siswa. Karena pada era ini untuk menekan penyebaran virus corona pembelajaran dilakukan dengan cara daring atau dalam jaringan. Pembelajaran daring dilakukan di rumah menjadi tanggungjawab orangtua dalam pengawasan terhadap anak-anaknya. Tujuan dalam penelitian ini adalah mengetahui dampak terhadap anak dalam meningkatkan keaktifan belajar siswa dalam penerapan pembelajaran daring sekaligus mengetahui dampak yang terjadi terhadap orangtua siswa yang anaknya mengikuti program pembelajaran daring. Penelitian ini menggunakan pendekatan kualitatif yang bersifat deskriptif, di mana penulis merupakan instrument utama untuk memperoleh data secara lebih rinci. Objek dalam penelitian ini adalah masyarakat di Padukuhan Mlangi Sawahan. Adapun teknik penentuan informan penelitian ini menggunakan purposive sampling. Teknik pengumpulan data dalam penelitian ini berupa observasi, wawancara, dan dokumentasi. Kemudian data yang sudah terkumpul dianalisis menggunakan reduksi data, penyajian data, dan kesimpulan. Hasil dari penelitian ini yaitu dengan diterapkannya pembelajaran daring di Padukuhan Mlangi Sawahan keaktifan belajar para siswa tidak meningkat, siswa tidak menyukai pembelajaran yang dilakukan dengan cara daring ini membuat siswa menjadi tidak aktif, siswa banyak bergantung kepada orangtuanya, siswa lebih senang dengan pembelajaran langsung di kelas membuat pembelajaran daring ini siswa menjadi bosan. Kemudian dampak terhadap orangtua dan anak yaitu siswa terbatas ruang berpikirnya membuat siswa tidak bisa bertukar pendapat dengan siswa lain serta tak bisa bertanya langsung dengan sang guru menjadikan siswa terlalu bergantung kepada orangtuanya setiap ada tugas dan menjadikan orangtua terganggu, orangtua harus menambah biaya untuk membeli paket internet supaya anak bisa mengikuti pembelajaran yang sedang diterapkan saat ini, pembelajaran daring para anak dan orangtua belum terbiasa dengan penggunaan teknologi menimbulkan kebingungan dengan penggunaanya.
\end{abstract}

Kata Kunci: dampak; pembelajaran daring; keaktifan belajar

Submitted Apr 13, 2021 | Revised Apr 21, 2021 | Accepted Apr 26, 2021 


\section{Pendahuluan}

Zaman 2020 masehi ini kita di gemparkan dengan adanya virus yang berasal dari Negara China yang cepat menyebar ke seluruh Negara di dunia. Hingga badan kesehatan dunia atau WHO menyatakan bahwa wabah virus corona ini ialah pandemi. Pandemi virus corona ini sangat mempengaruhi roda kehidupan di setiap Negara, yang dimana mengakibatkan perputaran kehidupasn menjadi berubah. Dari ekonomi, sosial hingga pendidikan. Dampak yang sangat terasa terjadi pada dunia pendidikan ialah, biasanya pembelajaran dari tingkat sekolah dasar sampai perguruan tinggi dilakukan diruang kelas, akan tetapi dengan adanya kasus pandemi ini dilakukan dengan cara yang sangat kental dikenal di zaman ini dengan kata pembelajaran daring (dalam jaringan) atau online.

Padukuhan Mlangi Sawahan adalah padukuhan yang terletak di Desa Nogotirto Kecamatan Gamping Kabupaten Sleman. Mendikbud mengeluarkan Surat Edaran Nomor 36962/MPK.A/HK/2020 agar seluruh kegiatan belajar mengajar baik di sekolah maupun kampus perguruan tinggi menggunakan metode daring (dalam jaringan) alias online sebagai upaya pencegahan terhadap perkembangan dan penyebaran Coronavirus disease (Covid-19). Banyak sekali kisah menarik, lucu, maupun sedih yang terjadi dalam proses belajar dengan metode ini. Bisa dilihat bagaimana gagapnya para pelaku pendidikan, stresnya orangtua yang mendampingi anak-anaknya belajar di rumah, dan tentunya bagaimana siswa kebingungan menghadapi tumpukan tugas yang aneh-aneh dari para pendidik yang sedang gagap.

Kegiatan pembelajaran yang efektif dengan cara daring (dalam jaringan) yang dilaksanakan sebagai kegiatan pembelajaran tentunya harus menggunakan jaringan internet agar dapat terhubung secara online. Dalam pembelajaran daring (dalam jaringan) harus mempersiapkan sarana dan prasarana yang menunjang agar kegiatan pembelajaran dapat dilaksanakan dengan baik (Wahyono, et al., 2020). Dengan adanya pembelajaran secara daring, peserta didik wajib ikut serta aktif di kegiatan pembelajaran berlangsung. Pada saat ini, pembelajaran daring merupakan pilihan utama yang dilaksanakan sebagai proses kegiatan pembelajaran selama masa pandemi covid-19.

Pembelajaran daring itu bukanlah berarti apa-apa untuk dunia perguruan tinggi, terutama bagi tenaga pengajar yang masih muda, karena mereka memang generasi yang tumbuh pada era digital atau jaringan. Sementara tenaga pengajar yang sudah lanjut usia dipaksa harus berlari menyesuaikan diri dengan cara baru itu. Walaupun tampak kesusahan, mereka harus siap untuk ikut perubahan. Tentu saja akan seru sekali jadinya karena pembelajaran daring di samping diperlukan kemampuan mengoperasionalkan jaringan dengan perangkatnya, juga harus dibekali pengetahuan daring.

Menjadi persoalan sebab pengetahuan daring sendiri belum menjadi bahan baku pembelajaran selama ini. Akhirnya, kita temukan tampilan pembelajaran daring yang bisa dibilang unik. Ada guru yang merekam mengajar berhadapan dengan bangku-bangku kosong, ada yang merekam mengajar lewat whatsapp kemudian dibagikan, ada yang mengirim tugas lewat whatsapp dan meminta jawaban lewat whatsapp, dan masih banyak lagi keunikan-keunikan pembelajaran daring seperti ini. Menjadi semakin ramai lagi kalau kita perhatikan pembelajaran di tingkat SMA dan SMK. (Sudjarwo, 2020)

Penulis melakukan pengamatan di Padukuhan Mlangi Sawahan, para pelajar sekolah melakukan pembelajaran daring dengan menggunakan aplikasi whatsapp. Dari program pembelajaran daring yang dijalankan tersebut, peneliti ingin meneliti apa dampak yang terjadi dengan pembelajaran daring di dusun Sawahan dalam membentuk keaktifan belajar. Keaktifan belajar siswa yaitu aktivitas siswa dalam proses belajar yang melibatkan kemampuan emosional dan lebih menekankan pada kreativitas siswa, meningkatkan kemampuan yang dimiliki, serta mencapai siswa yang kreatif dan mampu menguasai konsep-konsep (Riswani \& Widayati, 2012; Naziah, 2020). Pembelajaran aktif adalah pembelajaran yang bertujuan untuk meningkatkan mutu pendidikan. Untuk mencapai keterlibatan siswa agar efektif dan efisien dalam belajar, dibutuhkan berbagai pendukung di dalam proses pembelajaran, yaitu dari sudut siswa, guru, situasi belajar, program belajar dan dari sarana belajar. Keaktifan belajar merupakan suatu hal yang sangat berperan penting di dalam setiap peroses belajar mengajar. Dengan adanya daya 
keaktifan dari siswa di dalam proses pembelajaran, maka siswa sebgai peserta didik akan lebih cenderung akan memiliki rasa ketertarikan dan semangat yang tinggi dalam mengikuti proses kegiatan belajar mengajar (Desriadi, 2017; Kharis, 2019).

Berdasarkan latar belakang di atas, tujuan dalam penelitian ini adalah untuk mengetahui dampak terhadap anak dalam meningkatkan keaktifan belajar siswa dalam penerapan pembelajaran daring sekaligus mengetahui dampak yang terjadi terhadap orangtua siswa yang anaknya mengikuti program pembelajaran daring di Padukuhan Mlangi Sawahan.

\section{Metode Penelitian}

Penelitian ini menggunakan pendekatan kualitatif dan penelitian yang bersifat deskriptif analisis. Pendekatan pada penelitian ini menggunakan pendekatan deskriptif. Pendekatan deskriptif merupakan prosedur penelitian yang akan menghasilkan data-data deskriptif yang berupa kata-kata tertulis atau lisan dari orang, gambar, perilaku yang diamati, dan bukan angka-angka. Pendekatan deskriptif ini digunakan untuk mengetahui bagaimana pembelajaran daring bagi pelajar balam membentuk keaktifan belajar di dusun sawahan, nogotirto, gamping, sleman. Dalam penelitian ini Informan adalah subyek penelitian yang dapat memberikan informasi mengenai fenomena/permasalahan yang diangkat dalam penelitian. Informan pada penelitian ini yaitu para pelajar sekolah tingkat SD/MI dan para orangtua pelajar di dusun Sawahan yang mengikuti program pembelajaran daring. Peneliti juga menggunakan data sekunder berupa data yang dapat memberikan informasi yang relevan dengan tujuan penelitian. Alat pengumpulan data yang digunakan adalah observasi, wawancara dan dokumentasi. Pada penelitian kualitatif, data yang telah dikumpulkan dan didapatkan akan dianalisis dengan pendekatan kualitatif model interaktif yang terdiri dari tiga tahapan yaitu reduksi data, penyajian data, dan penarikan kesimpulan atau verifikasi.

\section{Hasil dan Pembahasan}

1. Bagaimana pembelajaran daring bagi pelajar dalam membentuk keaktifan belajar di Padukuhan Mlangi Sawahan?

Perlu diketahui bahwa data yang akan dibahas di bawah ini merupakan perolehan dari beberapa metode yang telah disebutkan oleh peneliti pada bab sebelumnya. Ada tiga metode yang digunakan untuk mendapatkan data ini yaitu melalui observasi di rumah-rumah warga yang melakukan pembelajaran daring guna melihat secara langsung apasaja yang terjadi di dusun Sawahan dalam proses pembelajaran tersebut. Kemudian wawancara dilaksanakan setelah observasi guna untuk menanyakan hal-hal apa saja yang ingin diketahui dan ditanyakan kepada informan terkait pertanyaan penelitian sekaligus menanyakan kejadian dari hasil observasi yang mengganjal sehingga ingin ditanyakan kepada informan untuk memperoleh kejelasan. Agar data yang didapatkan valid informan penelitian juga ada beberapa orang yang terdiri dari kepala dusun, orangtua, dan siswa. Supaya lebih jelas dalam pembahasan ini maka penulis perlu sedikit mengulas tentang pembelajaran daring di dusun Sawahan supaya lebih memudahkan menemukan inti permasalahan dan pembahasan dalam skripsi ini.

Pembelajaran daring di dusun Sawahan mengikuti anjuran dari pemerintah setelah wabah penyakit corona masuk ke Indonesia. Dengan keadaan tersebut, maka segala aspek dalam dunia pendidikan dilakukan dalam system online atau sebutan masa sekarang ialah daring kepanjangan dari dalam jaringan. Meski dengan anjuran pemerintah tersebut membuat segala tatanan yang sudah berlaku sebelumnya berubah dan yang pasti akan membuat para pelaku pendidikan khususnya orangtua dan anaknya harus segera bisa beradaptasi dengan kebiasaan baru tersebut sesuai dengan anjuran pemerintah, meski dengan segala keberatan dan kebingugan tersendiri bagi para pelaku yang masih gagal paham teknologi. Apalagi tidak semua warga di dusun Sawahan sudah memenuhi sarana prasarana pembelajaran daring seperti smartphone. Seperti yang dijelaskan oleh kepala dusun:

Bapak Mualif selaku kepala dukuh Sawahan mengatakan: 
"Saya belum pernah didatangi warga yang seperti itu, tapi saya dengar dari beberapa warga ada keluarga yang belum mempunyai smartphone ini mengikuti pembelajaran daring dengan cara mendatangi sekolah dan meminta tugas langsung lalu dikerjakan di rumah dan dikumpulkan tidak melalui online akan tetapi siswanya mengumpulkan tugasnya dengan mendatangi sekolah." (Mualif, 2020)

Menurut apa yang dituturkan oleh bapak Mualif, tidak semua warga dusun Sawahan sudah memiliki smartphone. Solusi bagi warga yang tidak memiliki sarana prasarana pembelajaran daring ialah dengan cara mendatangi sekolah untuk meminta tugas dan mengumpulkan tugas yang diberikan oleh sekolah. Sedangkan dari para orangtua yang anak-anaknya mengikuti pembelajaran daring.

Ibu Juminah mengatakan:

"Sarana prasarana pembelajaran online sudah ada dikeluarga saya, seperti hp kuota sudah ada." (Juminah, 2020)

Ibu Supriyati juga mengatakan:

"Sudah terpenuhi cuma kendalanya paket internet boros." (Supriyati, 2020)

Sedangkan Ibu Samsiyah mengatakan:

"Keluarga saya baru satu mingguan ini memilki hp. Yaa masih bingung juga menggunakannya." (Samsiyah, 2020)

Dari yang diutarakan oleh orangtua dan anak-anaknya, pembelajaran daring di dusun Sawahan ini memaksimalkan whatsapp dalam pembelajarannya. Dimana para siswa mendapatkan tugas dari sekolah dan dikerjakan di rumah. Ketika pelajar tidak memahami materi yang ditugaskan maka melalui whatsapplah siswa bertanya kepada guru.

Pembelajaran daring yang berjalan di dukuh Mlangi Sawahan ialah dengan cara sekolah memberikan tugas dan dikerjakan di rumah para siswa mengerjakan tugas dari sekolah tersebut didampingi dengan para orangtua. Ketika para siswa tidak memahami tugas yang diberikan oleh sekolah, para siswa bertanya melalui aplikasi whatsapp, yang memang pembelajaran daring ini adalah kepanjangan dari pembelajaran dalam jaringan. Pembelajaran daring ini memanfaatkan kemajuan teknologi jaman sekarang untuk menjalankan proses belajar mengajar tanpa bertatapmuka langsung di kelas.

Pada program pembelajaran daring ini jaringan internet sangat diperlukan untuk menunjang keberlangsungannya, walau di dusun Sawahan pembelajaran daring yang dilakukan hanya melalui aplikasi whatsapp, yang dimana masih sangat simple. Jaringan internet tetap menjadi nomer satu dalam melangsungkan pembelajaran. Karena jaringan internet ialah faktor utama pembelajaran online. fungsi dari jaringan internet ialah untuk menghubungkan beberapa orang yang terpisah dengan jarak dan waktu.

Pernyataan itu juga dikatakan oleh para ahli, Menurut Oetomo internet adalah singkatan atau singkatan dari international network, yang didefinisikan juga sebagai suatu jaringan komputer yang sangat besar, dimana jaringan komputer tersebut terdiri dari beberapa jaringan-jaringan kecil saling terhubung satu sama lain. Menurut Supriyanto Internet adalah suatu hubungan antara berbagai jenis komputer dan juga dengan jaringan di dunia yang punya sistem operasi dan juga aplikasi yang berbedabeda, dimana hubungan tersebut memanfaatkan kemajuan perangkat komunikasi semacam telepon dan satelit yang memakai protokol standar dalam melakukan hubungan komunikasi, yaitu protokol TCP/IP (Transmission Control/Internet Protocol).

Berdasar hasil yang diperoleh oleh peneliti, meliputi beberapa hasil berikut:

a) Media

Pembelajaran daring yang dilakukan di dusun Sawahan menggunakan media pengirim pesan yaitu whattsapp. Penggunaannya cukup unik, dimana para siswa dan orangtua menggunakan aplikasi ini untuk bertanya ketika tidak memahami materi yang dipelajari dan mengumpulkan tugas yang diberikan oleh guru. Cukup simple penggunaan medianya akan tetapi masih ada yang kebingungan menggunakannya 
karena baru memiliki perangkat pembelajaran daring. Seperti ibu Samsiyah yang baru saja memiliki smartphone baru satu mingguan membuat ibu Samsiyah kebingungan dalam mengikuti pembelajran daring. Dikarenakan pembelajaran daring di dusun Sawahan ini para siswa mengerjakan di rumah, maka para orangtua siswalah yang menjadi pendampingnya sekaligus menjadi tempat bertanya para anaknya ketika tidak memahami tugas yang diberikan. Seperti yang diutarakan para orangtua di atas serta anaknya bahwa ketika anak tidak memahami materi, maka para anak bertanya kepada orangtuanya. Ada juga yang bertanya kepada gurunya langsung melalui aplikasi whatsapp seperti yang dikatakan diatas oleh Lia. Ketika Lia tidak paham dengan tugas yang diberikan oleh sekolah, Lia akan bertanya kepada gurunya melalui whatsapp.

b) Metode

Metode pembelajaran yang digunakan di dusun sawahan dalam melaksanakan program pembelajaran daring ialah take and give yang dimana para siswa dituntut untuk mengerjakan tugas yang diberikan dan dipelajari di rumah sembari dikerjakan tugas yang diberikan dan dikumpulkan melalui aplikasi whatsapp dan bisa juga mendatangi sekolah untuk pengumpulannya. Semua itu berdasar sumber dari para informan penelitian. Setiap senin para siswa mendatangi sekolah untuk meminta tugas dan dikerjakan di rumah dengan didampingi oleh para orantuanya. Jatuh tempo pengumpulan tugasnya ialah di hari sabtu pada saat pengambilan tugasnya. Jadi diberi waktu dari hari senin untuk mengerjakan tugasnya dan dikumpul paling lambat di hari sabtunya.

Para pelajar di dusun Sawahan masih belum memaksimalkan aplikasi-aplikasi serta alamat web yang bisa menunjang keberlangsungannya pembelajaran daring. Mengingat sekarang ini sudah ada aplikasi dua layar yang memaksimalkan waktu secara realtime yang bisa menyatukan banyak orang sekaligus sebut saja aplikasi yang sudah popular seperti aplikasi zoom, ada juga google clashroom, ada juga alamat web ruangguru, zeniusid dan masih banyak lagi. Akan tetapi di dusun Sawahan pembelajaran daring tidak menggunakan itu, hanya menggunakan aplikasi whatsapp saja dalam pembelajarannya. Jadi terbilang masih sangat simple dan belum memaksimalkan aplikasi-aplikasi yang bisa menunjang pembelajaran daring.

2. Bagaimana keaktifan para pelajar di dusun Sawahan dengan adanya pembelajaran daring?

Dengan diterapkannya pembelajaran daring ini, para pelajar merasakan suasana berbeda dengan sebelumnya. Karena memang pembelajran daring ini adalah solusi dari pemerintah untuk mengantisipasi penyebaran virus corona. Dari penerapannya ini para pelajar sangat beragam mengenai keaktifannya dengan penerapan pembelajaran daring ini. Berikut pemaparan para pelajar di dusun Sawahan:

Adam mengatakan bahwa:

"Tidak aktif karena pembelajaran seperti ini sangat membosankan. setiap ada tugas lebih sering dikerjakan orangtua." (Adam, 2020)

Lia juga mengatakan:

"Lebih aktif kalau belajarnya di sekolah langsung. Kalau di rumah malas." (Lia, 2020)

Niswa juga mengatakan:

“Aktif kalau belajarnya di kelas. Kalo seperti ini saya bosan.” (Niswa, 2020)

Dari penjelasan para orangtua pelajar dusun Sawahan dijelaskan bahwa keaktifan para anaknya harus didampingi oleh orangtuanya. Karena memang pembelajaran daring dilangsungkan di rumah masing-masing dan menjadikan para orangtua sebagai pendamping dalam proses pembelajarannya. Mengingat proses pembelajaran daring di dusun Sawahan dilakukan melalui aplikasi whatsapp yang dimana hanya digunakan ketika siswa tidak memahami materinya untuk bertanya kepada gurunya dan tidak menggunakan aplikasi dua arah yang realtime seperti aplikasi zoom yang dimana aplikasi zoom bisa bertatapan langsung dengan guru secara realtime atau langsung dalam jaringan. Peneliti menarik 
pendapat daripada hasil wawancara dengan para informan bahwa keaktifannya para pelajar dusun Sawahan dalam program pembelajaran daring ini masih belum maksimal.

Kalau siswa yang bernama Lia dan Niswah menegrjakan sendiri kalau kurang paham akan bertanya langsung ke gurunya melalui aplikasi whatsapp terkadang Niswah juga bertanya kepada orangtuanya juga mencari tahu jawaban melalui mesin pencari gogel. Pernyataan itu mengindikasikan bahwa siswa tidak menikmati pembelajaran yang dilakukan serta tidak senang dengan program pembelajaran daring tersebut. Pernyataan para siswa selaras dengan apa yang diungkapkan oleh Nana Sudjana dalam keatifan belajar siswa yaitu: 1) Turut sertanya dalam mengerjakan tugas; 2) Terlibat dalam proses pemecahan masalah; 3) Bertanya kepada teman satu kelompok atau guru apabila tidak memahami persoalan yang sedang dihadapinya; 4) Melaksanakan diskusi kelompok sesuai dengan petunjuk guru; 5) Mampu mempresentasikan hasil kerjanya. (N.Sudjana, 2007)

Dalam pembelajaran daring di dusun Sawahan ini, para siswa tidak biasa dengan program pembelajaran yang dilakukan sekarang ini, membuat para siswa tidak menyukai dan keaktifannya berkurang dikarenakan pembelajaran daring mengharuskan setiap anak belajar di rumah membuat jasmani dan rohaninya tidak aktif mengikuti pembelajarannya. Pada pembelajaran daring di dusun Sawahan kali ini, siswa cenderung tidak aktif. Maka dari itu para siswa tidak menyukai pembelajaran seperti ini. Disamping tidak adanya dorongan dari dalam diri siswa, pembelajaran daring ini juga kurang mendapatkan ruang kepada teman-temannya yang dimana ketika pelajar bertemu dengan temannya langsung dalam situasi belajar akan mendorong keinginan belajar lebih aktif lagi. Pembelajaran daring ini juga para siswa kurang perhatian dan motivasi mengingat tidak semua orangtua bisa menjiwai menjadi guru dalam mendampingi anaknya belajar.

Pernyataan ini sejalan dengan apa yang dikemukakan oleh Nana Sudjana: 1) Stimulus Belajar; 2) Perhatian dan Motivasi; 3) Respon yang dipelajarinya; 4) Penguatan; 5) Pemakaian dan Pemindahan. (N.Sudjana, 2007)

Menurut pernyataan dari Gagne dan Brigss diatas dengan proses pembelajaran yang sedang dijalankan di Padukuhan Mlangi Sawahan, proses yang diberlakukan tidak bisa menjalankan apa yang telah dinyatakan oleh Gagne dan Brigss. Dikarenakan pembelajaran di Padukuhan Mlangi Sawahan ini penulis mengamati bahwa sekolah menerapkan pembelajaran yang tumpu keaktifannya berada di tangan siswa. Akan tetapi dengan proses pembelajaran yang dijalankan sekarang ini di Padukuhan Mlangi Sawahan membuat siswa tidak semangat untuk belajar.

Pembelajaran daring yang dilakukan di Padukuhan Mlangi Sawahan menimbulkan suasana yang berbeda seperti sebelum pandemi covid ini dan membuat para siswa sulit beradaptasi dan memahami pelajaran yang dijalankan. Program pembelajaran ini membuat keaktifan para siswa berkurang. Dengan situasi program pembelajaran seperti ini, sejalan dengan Syaiful Sagala bahwa faktor yang mempengaruhi keaktifan siswa antara lain: 1) Perhatian; 2) Pengamatan; 3) Tangapan; 4) Fantasi; 5) Ingatan; 6) Bakat; 7) Berfikir; 8) Motif. (Syaiful Sagala, 2013)

Hasil dari observasi dan wawancara di dusun Sawahan, program pembelajaran daring ini membuat siswa tidak mendapatkan perhatian dari sang guru, siswa juga tidak bisa memaksimalkan panca indera untuk melakukan pengamatan disekitar. Berbeda dengan pembelajaran langsung di kelas, siswa bisa memaksimalkan panca inderanya. Pembelajaran daring ini siswa hanya disuruh untuk mengerjakan tugas dan mengumpulkannya tanpa adanya pengamatan di sekitar.

Situasi ini juga menimbulkan tanggapan para siswa menyempit dikarenakan hanya berpacu pada tugas dan tidak memiliki kesempatan menanggapi pembelajarannya. Serta siswa tidak longgar dalam berfantasi dalam program pembelajaran daring ini. Program ini juga menyempitkan siswa dalam berfikir serta menyimpulkan pengertian tentang materi yang disampaikan oleh guru dikarenakan guru hanya memberi siswa tugas dan dikerjakan di rumah dengan didampingi oleh para orantuanya dan dengan situasi dan kondisi seperti ini, beban pembelajaran juga berada pada para orangtua siswa. Ditambah lagi faktor yang membuat siswa kurang aktif dalam belajar adalah keadaan keluarga yang 
belum memadai dalam menjalankan program pembelajran daring, di dusun Sawahan masih ada yang kurang memahami kegunaan teknologi saat ini yang membuat kebingungan dalam mengikuti pembelajaran daring. Semua faktor itu, menimbulkan keaktifan siswa dalam belajar juga berkurang.

3. Dampak dari pembelajaran daring bagi pelajar dan orangtua?

Setiap sesuatu yang dijalankan pasti ada dampak dari sesuatu tersebut, apalagi konteks yang penulis teliti ialah pembelajaran daring yang dimana program pembelajaran ini sangatlah baru dan mau tidak mau harus dilakukan untuk menekan penyebaran virus corona, maka dari itu dengan penerapan pembelajaran daring ini. Peneliti akan mengulas tentang dampak dari diterapkannya pembelajaran daring bagi para pelajar dan orangtua. Peneliti mendapatkan hasil dari para informan.

Ibu Juminah selaku orangtua dari Adam mengatakan:

"Yaa sangat mengganggu, seperti ketika saya akan melakukan kegiatan seperti biasanya sebelum masa-masa seperti ini tidak menjadi masalah. Nahh setelah masa-masa ini kegiatan saya selalu terganggu dengan mau tidak mau saya harus membantu mengawasi serta menjelaskan pelajaran yang tidak begitu saya pahami kepada anak saya karena yaa sekarang ini memang pembelajaran dilakukan di rumah.” (Juminah, 2020)

Ibu Supriyati juga mengatakan:

"Sangat mengganggu, yaa setiap saya ingin melakukan kegiatan seperti biasa kadang anak bertanya dan meminta untuk menemani belajar terutama anak saya yang kelas satu itu kan baru awal-awal masuk sekolah ini yang berbeda dengan masa taman kanak-kanak maka suasananya berbedalahh dari dulu maka selalu saya dampingi. Untuk lia yang kelas enam yaa bisa sendiri kadang tanya langsung kepada gurunya melalui wa, kalau wafi harus saya yang mendampingi. Intinya yaa sangat mengganggulah.” (Supriyati, 2020)

Ibu Samsiyah mengatakan:

"Sangat mengganggu. Setiap saya akan melakukan ini itu kadang anak meminta bantuan untuk mengerjakan tugas dan pastinya itu sangat mengganggu saya." (Samsiyah, 2020)

Dari informasi para orangtua bahwa disebutkan dampak dari pembelajaran daring itu sangat mengganggu aktifitasnya. Ketika akan melakukan sesuatu terbentur dengan pembelajaran anak yang menjadi tanggungjawab orangtua karena pembelajarannya dilakukan di rumah masing-masing. Sebelumnya yang dimana pembelajaran daring ini belum diterapkan yang pasti tanggungjawab pembelajaran sepenuhnya berada di sekolah dan menjadi tugas para guru untuk mendampingi para siswanya belajar. Begitu juga dampak pembelajaran daring ini yang diungkapkan para anaknya sebagai berikut:

Adam anak dari ibu Jumianah:

"Tidak paham dan sering tanya kepada ibu daripada tanya kepada guru." (Adam, 2020)

Lia anak dari ibu Supriyati:

"Kadang paham kadang tidak." (Lia, 2020)

Niswah anak dari ibu Samsiyah:

"Tidak paham." (Niswa, 2020)

Dari penjelasan para siswa tersebut adalah bahwa pembelajaran daring ini mereka tidak memahami materi yang disampaikan oleh guru. Karena memang pembelajaran daring sekolah menyiapkan tugas-tugas untuk dikerjakan di rumah tanpa adanya penjelasan materi. Ketika pembelajaran daring berlangsung, yang dilakukan di dusun Sawahan ini tidak menggunakan aplikasi realtime hanya menggunakan aplikasi whatsapp dan digunakan untuk bertanya ketika anak tidak memahami materi akan tetapi anak lebih sering tanya kepada orangtuanya daripada bertanya kepada guru. Begitu juga anak lebih senang ketika pembelajaran itu dilakukan secara langsung seperti yang diungkapkan oleh para siswa:

Adam mengatakan: 
"Tidak setuju, karena lebih enak pergi ke sekolah dan bertemu guru langsung dalam belajar." (Adam, 2020)

Lia mengatakan:

"Tidak setuju karena lebih enak bertemu langsung dengan guru dan bisa lebih paham kalau pembelajarannya dilakukan di kelas. Di rumah sulit untuk memahami pelajaran.” (Lia, 2020)

Niswah mengatakan:

"Tidak setuju karena lebih ribett tidak seperti biasanya dulu di kelas lebih gampang memahami pelajaran.” (Niswa, 2020)

Hasil yang didapat peneliti dari para siswa ketika pembelajaran daring ini mereka lebih sulit memahami materi dan juga lebih senang kalau pembelajaran dilakukan dengan mendatangi sekolah dan bertemu guru langsung di kelas. Pembelajaran daring ini memang sangat diperlukan untuk saat ini mengingat untuk menekan penyebaran virus corona, akan tetapi tidak baik jika dilakukan secara terus menerus atau permanen. Seperti yang dikatakan oleh bapak Mualif selaku kepala dusun Sawahan:

"Kalau tidak dalam masa pandemi tidak cocok, artinya sekolah itu idealnya memang harus ada tatap muka antara guru dan murid. Karena bagaimanapun tidak semua pelajaran bisa disampaikan secara jarak jauh, ada beberapa hal yang harus ada ikatan langsung untuk menyampaikan pelajaran-pelajaran yang harus disampaikan. Jadi kalau daring ini khusus untuk masa pandemi." (Mualif, 2020)

Berdasar hasil dari para informan dampak yang ditimbulkan dengan diterapkannya pembelajaran daring di dusun Sawahan dampaknya tidak baik atau negatif bagi para pelajar beserta orangtuanya. Akan tetapi pembelajaran daring ini harus dilakukan mengikuti anjuran pemerintah dimasa pandemi corona ini untuk menekan penyebaran virus tersebut.

\section{Kesimpulan}

Bentuk pembelajaran daring yang dilakukan di Padukuhan Mlangi Sawahan pertama, dengan cara para siswa mendatangi sekolah di hari senin dan diberikan tugas untuk dikerjakan di rumah waktu jatuh tempo pengumpulannya di hari sabtu. Kedua, aplikasi whatsapp sebagai sarana utama dalam proses komunikasi antar siswa dan guru. Ketiga, orangtua menjadi pembimbing serta pengarah dalam belajar anak di rumah menggantikan posisi guru yang terbatas akan ruang dan waktu. Dengan diterapkannya pembelajaran daring di Padukuhan Mlangi Sawahan keaktifan belajar para siswa tidak meningkat. Karena pertama, para siswa tidak menyukai pembelajaran yang dilakukan dengan cara daring ini membuat siswa menjadi tidak aktif. Kedua, para siswa banyak bergantung kepada orangtuanya. Ketiga, para siswa lebih senang dengan pembelajaran langsung di kelas membuat pembelajaran daring ini siswa menjadi bosan. Dampak bagi siswa dan orangtua dalam penerapan pembelajaran daring ini, para siswa terbatas ruang berpikirnya membuat siswa tidak bisa bertukar pendapat dengan siswa lain serta tak bisa bertanya langsung dengan sang guru menjadikan siswa terlalu bergantung kepada orangtuanya setiap ada tugas dan menjadikan orangtua terganggu.

\section{Daftar Pustaka}

Arnesti, N., \& Hamid, A. (2015). Penggunaan media pembelajaran online-offline dan komunikasi interpersonal terhadap hasil belajar bahasa inggris. Jurnal Teknologi Informasi \& Komunikasi Dalam Pendidikan, 2(1).

Am, S. (2001). Interaksi Dan Motivasi Belajar Mengajar. Jakarta: Raja Grafindo Persada.

Desriadi, D. (2017). Strategi Guru Dalam Meningkatkan Keaktifan Belajar Siswa Pada Mata Pelajaran PAI di SMA Muhammadiyah Gunung Meriah Aceh Singkil. At-Ta'dib: Jurnal Ilmiah Prodi Pendidikan Agama Islam, , 151-162.

Hamalik, O. (2008). Kurikulum dan Pembelajaran. Jakarta: Bumi Aksara. 
Hardyanto, R. H., \& Surjono, H. D. (2016). Pengembangan dan implementasi e-learning menggunakan moodle dan vicon untuk pelajaran pemrograman web di SMK. Jurnal Pendidikan Vokasi, 6(1), 4353.

Kharis, A. (2019). Upaya peningkatan keaktifan siswa melalui model pembelajaran picture and picture berbasis IT pada tematik. MIMBAR PGSD Undiksha, 7(3).

Martinis, Y. (2007). Kiat Membelajarkan Siswa. Jakarta. Gaung Persada Press dan Center for Learning Innovation (CLI).

Muhammad, A. (2008). Guru Dalam Proses Mengajar. Bandung: Sinar Baru Algensindo.

Munir. (2009). Pembelajaran Jarak Jaub Berbasis Teknologi Informasi Dan Komunikasi. Bandung: Alfabeta.

Nana, S. (2007). Penilaian Hasil Proses Belajar Mengajar. Bandung: PT Remaja Rosdakarya.

Naziah, S. T., Maula, L. H., \& Sutrisna, A. (2020). Analisis keaktifan belajar siswa selama pembelajaran daring pada masa covid-19 di sekolah dasar. Jurnal JPSD, 7(2), 109-120.

Nurdin \& Usman. (2011). Implementasi Pembelajaran. Yogyakarta: Rajawali Press.

Riswani, E. F., \& Widayati, A. (2012). Model active learning dengan teknik learning starts with a question dalam peningkatan keaktifan peserta didik pada pembelajaran Akuntansi kelas XI ilmu sosial 1 SMA Negeri 7 Yogyakarta Tahun Ajaran 2011/2012. Jumal Pendidikan Akuntansi Indonesia, 10(2).

Tjokro, S. (2009). Presentasi yang Mencekam. Jakarta: Elex Media Komputindo.

Wahyono, P., Husamah, H., \& Budi, A. S. (2020). Guru profesional di masa pandemi COVID-19: Review implementasi, tantangan, dan solusi pembelajaran daring. Jurnal pendidikan profesi guru, 1(1), 51-65.

Wibowo, N. (2016). Upaya peningkatan keaktifan siswa melalui pembelajaran berdasarkan gaya belajar di SMK Negeri 1 Saptosari. Elinvo (Electronics, Informatics, and Vocational Education), 1(2), 128-139. 